\title{
Breeding Strawberries at the Decaploid Level
}

\author{
Hamid Ahmadi and Royce S. Bringhurst ${ }^{1}$ \\ Pomology Department, University of California, Davis, CA 95616 \\ Additional index words. Fragaria, unreduced gametes, day neutral, chromosome number
}

\begin{abstract}
Two groups of Fragaria decaploid $(2 \mathrm{n}=70, \mathrm{x}=7)$ breeding populations were studied. The first was derived from pentaploid $(2 n=35)$ and hexaploid $(2 n=42)$ natural or synethetic interspecific hybrids between octoploid $(2 \mathrm{n}=56) F$. chiloensis $(\mathrm{L}$.) Duch. or $\boldsymbol{F}$. virginiana Duch. both from California, and various Fragaria diploids $(2 \mathrm{n}=14)$. Their chromosome number was doubled with colchicine or through the naturally generated unreduced gametes. They were selfed repetitively, intercrossed, and open pollinated. Gametic viability of the hermaphroditic and female decaploid hybrids exceeded $50 \%$. The hybrids exhibited heterosis for runner production and vegetative vigor. Fragaria chiloensis bred for large fruit and desirable fruit qualities, and, in combination with diploids $F$. vesca $L$. and $F$. viridis Duch., resulted in hybrids that produced a single early spring crop and prolific runner production throughout the summer. Fragaria virginiana L. derivatives were characterized by high pollen fertility, and by day neutrality (photo-insensitivity). Together, they may contribute genes for adaptation to various regions and climates of the world and for pest and disease resistance. The second and most important group of decaploids involved here were those derived from hybrids between day-neutral octoploid cultivars $(F$. xananassa) crossed to $F$. vesca or $F$. viridis. This group of decaploids combined the genomes of the best octoploid cultivars with those of the above diploid species: facilitating the incorporation of genes responsible for high yield, day neutrality, and excellent fruit quality into the decaploid strawberries.
\end{abstract}

Polyploidization is the principal evolutionary force involved in the development of many of the cultivated fruit crops, including: plums (Prunus domestica L.), sour cherries (P. cerasus L.) blackberries (Rubus spp.), highbush (Vaccinium corymbosum L.) and rabbiteye blueberries (V. ashei Reade), strawberries and kiwifruit [Actinidia deliciosa (A. Chev.)], all of which are allo- and/or auto-polyploids (Darrow, 1966; Janick and Moore, 1975; Jennings, 1988; Warrington and Weston, 1990). Some of these crops, such as octoploid strawberries, hexa- and heptaploid hybrids of blackberries and raspberries, tetra- and hexaploid blueberries, polyploid currants, and kiwifruit, were domesticated recently and are indeed new crops.

For species differing in ploidy levels or with semi-incompatible mating barriers and adaptive ecological differentiation, additional polyploidization may be the most rapid and efficient procedure for using their germplasm to generate new wild forms or cultivars with improved adaptation. Amphiploid blackberryraspberry hybrids (Jennings, 1988) and natural decaploid derivatives of penta-, hexa-, and enneaploid hybrids of overlapping populations of $F$. chiloensis and $F$. vesca in California (Bringhurst and Gill, 1970; Bringhurst and Khan, 1963; Senanayake and Bringhurst, 1967) are examples of the above process. The functioning of unreduced mega- and microspores from the semisterile to semi-fertile interspecific hybrids is the mechanism most likely to advance this evolutionary process in nature. In addition, functional unreduced gametes may expedite the transfer of desirable genes from lower ploidy levels of wild or commercial progenitors to higher ploidy levels of fruit crops such as blueberries, blackberries, and strawberries (Jennings, 1988; Vorsa and Ballington, 1991).

Many investigators have employed unreduced gametes to produce new synthetic clones of strawberries at various ploidy levels. Yarnell (1931) reported the synthesis of decaploid and enneaploid strawberry seedlings from semi-sterile pentaploid $F$. vesca $\times F$. chiloensis hybrids via unreduced gametes. Lilianfeld

Received for publication 13 Sept. 1991. Accepted for publication 20 Apr. 1992. We thank Carole Meredith and Fredrick Bliss for their critical reading and helpful comments The cost of publishing this paper was defrayed in part by the payment of page charges. Under postal regulations, this paper therefore must be hereby marked advertisement solely to indicate this fact.

'To whom reprint requests should be addressed.
(1934) and Federova (1934) subsequently reported pentaploid seedlings via unreduced gametes from $F$. moschata Duch. (2n $=42) \times F$. nipponicaa Mak. $(2 \mathrm{n}=14)$ and $F$. vesca $\times$. moschata, respectively. Scott (1951) obtained six fully fertile, short-day decaploid offspring from a hexaploid cultivar $\mathrm{x}$ tetraploid 'Alpine' $F$. vesca hybrids open pollinated to octoploid cultivars. Bauer and Grubler (1962), Bauer and Bauer (1979), MacIntyre and Gooding (1977), and Spiegler et al. (1986) used the same technique to obtain somewhat improved decaploid shortday strawberries. Bringhurst and Khan (1963) and Bringhurst and Senanayake (1966) discovered vigorous sterile to semi-fertile natural pentaploid and hexaploid hybrids in overlapping populations of $F$. chiloensis and $F$. vesca in California. Bringhurst (1990), also obtained a semi-fertile hybrid of $F$. iinumae Mak. with $F$. virginiana.

In the investigation reported here, semi-fertile pentaploids and fully fertile colchicine or naturally derived decaploids were obtained by combining genomes from wild populations of diploid $F$. vesca including perpetual-flowering 'Alpine' and $F$. viridis from Europe, with those of the several octoploid species, including $F$. xananassa day-neutral cultivars. Horticultural characteristics such as yield, fruit size, and fruit quality were evaluated in their offspring. The objectives of this study were to: 1) assess the possibility of obtaining fertile decaploid clones with sufficient desirable traits to form the basis for a breeding program at the decaploid level, using genes from various diploid species; 2) compare the efficiency of breeding procedures leading to diverse decaploid populations; and 3) describe and evaluate the horticultural attributes of selected decaploid strawberries.

\section{Materials and Methods}

The origin and fertility of decaploid and other ploidy levels of Fragaria resulting from various hybridizations are shown in Table 1.

I) $8 x$ x $2 x \rightarrow 5 x$ (colchicine doubled) $\rightarrow 10 x$. One of the most useful octoploids was a wild clone of $F$. virginiana ssp. platypetala Rydb. from Luther Pass, Calif. (designated as 'Luther', Table 2). 'Luther' was hybridized with $F$. viridis (designated progeny 83.242 ). The chromosomes of the hybrids were counted after the method of Bringhurst and Gill (1970), and the genome of the most vigorous seedling was synthetically doubled with 


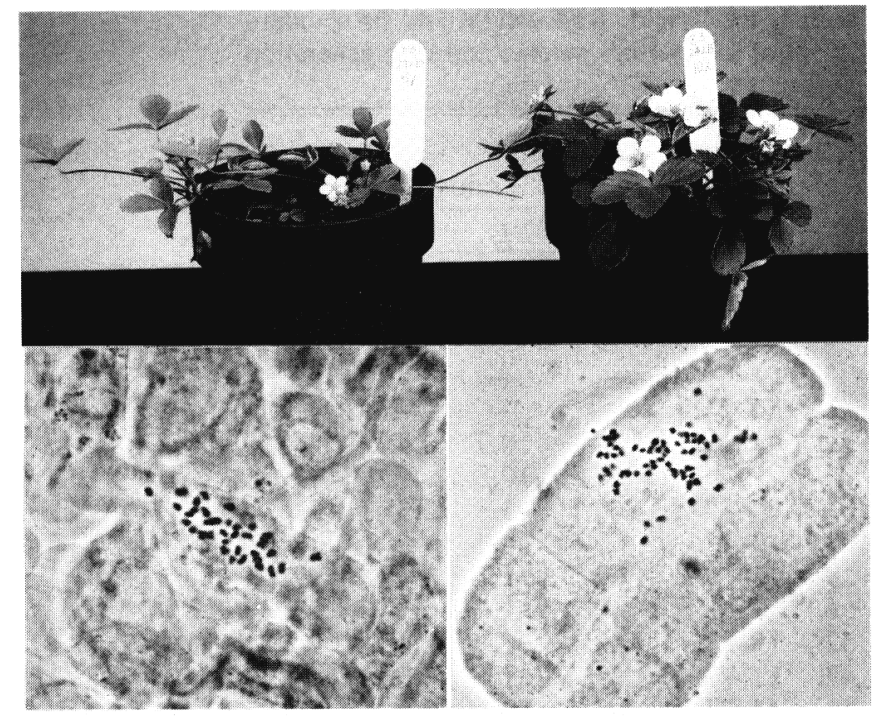

Fig. 1. Fragaria virginiana $\mathrm{x} F$. viridis interspecific hybrids. Top left, pentaploid selection 83.242; top right, interspecific colchi-decaploid 83.242-1; bottom left (magnification, $\times 146$ ), the chromosal compliment of the pentaploid selection $83.242(\mathrm{x}=7,2 \mathrm{n}=35)$; bottom right (magnification, $\times 233$ ), the chromosomal compliment of the interspecific decaploid 83.242-1 $(\mathrm{x}=7,2 \mathrm{n}=70)$.

colchicine (designated selection 83.242-1). The same procedure was followed to obtain a decaploid $F$. chiloensis $(\mathrm{CMCl}) \times$ 'Alpine' F. vesca hybrid (designated selection 85.926-1). Three previously doubled natural pentaploid interspecific hybrids of $F$. chiloensis and $F$. vesca from California were also incorporated into the current investigations. They were identified as female CA 1614 and hermaphrodites CA 1325 and CA 1349.
The above clones and a 10x selfed derivative of CA 1349 (designated selection 67.200-2) were selfed or hybridized to 83.2421 and their seedlings were evaluated in the field near Davis, Calif., in 1986. Their ploidy level, the relative success of the hybridization, and the viability of their gametes are noted in Table 1 (designated Ia-Id, Ih, and Ii).

The designation system of Univ. of California, Davis, strawberry accession or pedigree numbers are used throughout this manuscript because some of the clones involved are preserved at the National Clonal Germplasm Repository, Corvallis, Ore., and may be accessed through these numbers.

II) $8 x \times 2 x$ (unreduced) $\rightarrow 6 x$ (unreduced) $\mathrm{x} 8 x \rightarrow 10 x$. A natural female hexaploid of $F$. chiloensis and $F$. vesca (designated CA 1327) reported by Bringhurst and Senanayake (1966) was hybridized to 'Aliso' and two of their decaploid hybrids that resulted from unreduced hexaploid gametes (72.531-2 and 72.531-4) were hybridized to 83.242-1 (designated as progenies 86.831 and 86.832). More than 200 of their hybrids were field evaluated near Davis in 1986. Open-pollinated seeds from the outcrossing female and self-fertile hermaphroditic decaploid seedlings from these populations were germinated and grown near Davis in 1987 and were designated progenies 87.813 and 87.814, respectively (Table 1 , designated IIa-IIc and in Table 2).

III) $12 x \times 8 x \rightarrow 10 x$ or $16 x \times 4 x \rightarrow 10 x$. The chromosome number of five octoploid cultivars was doubled and the derived fertile clones were hybridized to octoploid cultivars. All $12 \mathrm{x}$ offspring were invariably sterile. It should be noted that the dodecaploid (12x, polytriploids) are fairly commonly found in octoploid breeding populations; they are absolutely sterile and thus do not hybridize with octoploid cultivars (Table 1, designated IIIa-IIId).

A colchi-tetraploid clone of 'Alpine' $F$. vesca was synthesized, its pollen viability and its seed fertility were examined

Table 1. Natural and synthetic origin of California decaploid (10x) Fragaria and other ploidy levels from octoploid (8x) and diploid (2x) species and cultivars (I-II), higher ploidy levels form octoploid cultivars (III) and from hexaploid $F$. moschata (IV).

\begin{tabular}{|c|c|c|c|c|}
\hline $\begin{array}{l}\text { Designa- } \\
\text { tion }\end{array}$ & Parental ploidy and (gamete origin) & $\begin{array}{l}\text { Offspring } \\
\text { ploidy }\end{array}$ & $\begin{array}{l}\text { Ease of } \\
\text { crossing }\end{array}$ & $\begin{array}{l}\text { Offspring } \\
\text { fertility }\end{array}$ \\
\hline I & $8 \mathrm{x}$ (reduced) $\times 2 \times$ (reduced) & $5 x$ & Fair & Low \\
\hline $\mathrm{b}$ & $5 \mathrm{x}$ (doubled with colchicine) & $10 \mathrm{x}$ & High & High \\
\hline c & $5 \mathrm{x}$ (unreduced) $\times 5 \times$ (unreduced) & $10 \mathrm{x}$ & High & High \\
\hline $\mathrm{d}$ & $5 \mathrm{x}$ (reduced or unreduced) $\mathrm{x}$ same & Various $^{\mathbf{z}}$ & Low & High \\
\hline . & $5 \mathrm{x}$ (unreduced) $\times 8 \mathrm{x}$ (reduced) & $9 \mathrm{x}$ & High & Medium \\
\hline f & $8 \times$ (unreduced) $\times 2 \times$ (reduced) & $9 \mathrm{x}$ & High & Medium \\
\hline$g$ & $5 x$ (reduced) $\times 8 x$ (reduced) & Various $^{\mathbf{z}}$ & Medium & Medium \\
\hline $\mathrm{h}$ & $5 \times$ (unreduced $) \times 10 \times$ (reduced $)$ & $10 \mathrm{x}$ & High & High \\
\hline & $5 \mathrm{x}$ (reduced) $\times 10 \mathrm{x}$ (reduced $)$ & Various ${ }^{z}$ & Low & Low \\
\hline II & $8 \times$ (reduced) $\times 2 \times$ (unreduced) & $6 x$ & Low & Fair \\
\hline $\mathrm{b}$ & $6 \mathrm{x}$ (unreduced) $\times 8 \times$ (reduced) & $10 \mathrm{x}$ & High & High \\
\hline c & $6 \mathrm{x}$ (reduced) $\times 8 \times$ (reduced $)$ & --- & Failed & --- \\
\hline III & $8 x$ doubled with colchicine & $16 \mathrm{x}$ & Medium & Good \\
\hline $\mathrm{b}$ & $8 \mathrm{x}$ (unreduced) $\times 8 \mathrm{x}$ (reduced) & $12 x$ & Low & Sterile \\
\hline c & $16 \times$ (reduced) $\times 8 \times$ (reduced) & $12 x$ & Low & Sterile \\
\hline d & $12 \times($ reduced $) \times 8 \times$ (reduced $)$ & --- & Failed & --- \\
\hline e & $16 \mathrm{x}$ (reduced) $\times 4 \times$ (reduced) & --- & Failed & --- \\
\hline IV & 6x F. moschata doubled & $12 x$ & High & High \\
\hline $\mathrm{b}$ & $12 \mathrm{x} F$. moschata $\times 8 \mathrm{x}$ (reduced) & --- & Failed &.-- \\
\hline c & $12 \times F$. moschata $\times 6 \mathrm{x}$ (reduced) & $9 \mathrm{x}$ & Good & Good \\
\hline 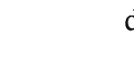 & $\begin{array}{l}9 \mathrm{x} F \text { moschata (reduced) } \times 10 \mathrm{x} \\
\quad \text { (reduced) }\end{array}$ & -- & Failed & -- \\
\hline
\end{tabular}

zIncluding aneuploidy and incomplete sets of chromosomes. 
Table 2. Ploidy and size, range in size and fertility of pollen, total yield, fruit weight and its standard deviation (so); and number of runners per strawberry plant of 1982-1988 parents and first generation offspring.

\begin{tabular}{|c|c|c|c|c|c|c|c|c|c|c|}
\hline \multirow[b]{3}{*}{ Item } & \multirow[b]{3}{*}{ Ploidy } & \multirow{3}{*}{$\begin{array}{l}\text { Obsv. } \\
\text { (no.) }\end{array}$} & \multicolumn{4}{|c|}{ Pollen } & \multirow{3}{*}{$\begin{array}{c}\text { Total } \\
\text { yld/plant } \\
\text { g/plant }\end{array}$} & \multirow{2}{*}{\multicolumn{2}{|c|}{ Fruit size }} & \multirow{3}{*}{$\begin{array}{l}\text { Runners } \\
\text { plant }\end{array}$} \\
\hline & & & \multicolumn{2}{|c|}{ Size $(\mu)$} & \multicolumn{2}{|c|}{ Fertility } & & & & \\
\hline & & & Mean & Range & $\%$ & Range & & $\mathrm{g}$ & $\mathrm{SD}$ & \\
\hline $\mathrm{CA} F$. vesca ${ }^{z}$ & $2 x$ & 4 & 22 & $17-24$ & 79 & $72-88$ & 5 & 0.5 & 0.3 & 63 \\
\hline F. viridis & $2 \mathrm{x}$ & 2 & 19 & $16-24$ & 68 & $56-82$ & -- & -- & --- & 48 \\
\hline F. vesca ${ }^{\mathrm{y}}$ & $2 \mathrm{x}$ & 1 & 19 & $17-24$ & 99 & -- & 19 & 0.7 & 0.3 & 33 \\
\hline 85.926 & $5 x$ & 28 & 31 & $27-34$ & 2 & $1-3$ & -- & -- & -- & 57 \\
\hline 83.242 & $5 x$ & 4 & 32 & $28-33$ & 1 & $0-2$ & $-\cdots$ & -- & --- & 68 \\
\hline 'Luther' & $8 \mathrm{x}$ & 1 & 26 & $21-30$ & 89 & -.. & 24 & 0.7 & 0.4 & 34 \\
\hline 'Fern' & $8 x$ & 1 & 27 & $24-30$ & 84 & -- & 1467 & 10.5 & 5.7 & 27 \\
\hline 'Fern' x 'Luther' & $8 x$ & 30 & 27 & $22-30$ & 87 & $80-97$ & 260 & 3.8 & 2.1 & 31 \\
\hline 88.910 & $9 \mathrm{x}$ & 136 & 31 & $23-44$ & 3 & $0-17$ & 0.6 & -- & $\ldots$ & 18 \\
\hline 86.832 & $10 \mathrm{x}$ & 86 & 29 & $25-33$ & 59 & $12-86$ & 57 & 1.1 & 0.4 & 97 \\
\hline 86.831 & $10 \mathrm{x}$ & 131 & 29 & $24-35$ & 56 & $8-83$ & 49 & 1.0 & 0.3 & 93 \\
\hline 87.813 & $10 \mathrm{x}$ & 123 & 29 & $24-33$ & 52 & $15-83$ & 48 & 1.0 & 0.3 & 84 \\
\hline 87.814 & $10 \mathrm{x}$ & 92 & 29 & $24-33$ & 47 & $22-77$ & 39 & 1.0 & 0.5 & 58 \\
\hline $67.200 \times$ Self & $10 \mathrm{x}$ & 24 & 30 & $25-33$ & 64 & $43-77$ & 38 & 2.4 & 0.5 & 72 \\
\hline $1349 \times 83.242-1$ & $10 \mathrm{x}$ & 24 & 30 & $25-33$ & 64 & $43-77$ & 22 & 1.2 & 0.4 & 83 \\
\hline $85.926-1$ & $10 \mathrm{x}$ & 1 & 31 & $28-36$ & 87 & --- & 18 & 2.9 & 0.4 & 63 \\
\hline $83.242-1$ & $10 \mathrm{x}$ & 1 & 29 & $26-33$ & 94 & --. & 9 & 0.6 & 0.2 & 77 \\
\hline $83.242-1 \times$ Self & $10 \mathrm{x}$ & 183 & 30 & $26-33$ & 93 & $89-96$ & 7 & 0.5 & 0.2 & 79 \\
\hline 85.926-1 x Self & $10 \mathrm{x}$ & 148 & 31 & $28-35$ & 81 & $70-89$ & 28 & 2.4 & 0.7 & 61 \\
\hline
\end{tabular}

${ }^{2}$ Native California clone.

'European clone 'Alpine'.

'California clone of $\mathrm{F}$. virginiana ssp. platypetala.

"F $\mathrm{x}$ ananassa.

(Table 2), and then it was hybridized to six colchi-16x clones of $F$. xananassa and $F$. chiloensis (CMC1, 16x). The resulting seeds were shriveled and infertile (Table 1, designated IIIe).

IV) F. moschata $12 x \times 8 x \rightarrow 10 x$ or $12 x \times 6 x \rightarrow 9 x \times 10 x$ $\rightarrow 10 x$. The chromosome number of a highly fertile female clone of $F$. moschata $(2 \mathrm{n}=42, \mathrm{x}=7)$ was doubled with colchicine, asexually propagated, and the dodecaploid propagules were interplanted with many octoploid clones of $F$. chiloensis, $F$. virginiana, $F . \times$ ananassa cultivars and with 'Capron', a hexaploid hermaphroditic cultivar of $F$. moschata (Table 1, designated IVa-IVd). Hybridization was successful with 'Capron' only, and the derived enneaploids were all fertile males or females. More than 150 enneaploid seedlings were interplanted with large populations of octoploid species and decaploid interspecific selections of Fragaria near Davis in 1988. Seeds were collected from female enneaploid seedlings, germinated, and examined for interspecific species hybrids; none was found.

Day-neutral decaploid clones. 'Mrak', an $F$. × ananassa cultivar, was selfed, and one of its vigorous day-neutral offspring was hybridized with $F$. vesca 'Alpine' to obtain a semi-sterile day-neutral pentaploid clone (designated selection 87.803-1) that was multiplied in the greenhouse and then interplanted with decaploid populations near Davis and with octoploid F. $\times$ ananassa cultivars in Watsonville, Calif., in 1987. The open-pollinated seeds of 87.803-1 from the above two locations gave rise to two large populations (designated progenies 88,909 and 88.910, respectively), grown near Davis in 1988.

A vigorous, triple-selfed homozygous day-neutral derivative of 'Fern' (a day-neutral $F$. x ananassa cultivar) also was hybridized with $F$. viridis and the semi-sterile day-neutral pentaploid hybrid was designated selection 87.802-1. It was hybridized with decaploid 85.926-1 in the greenhouse in Davis in 1987 and its semi-fertile decaploid offspring (designated 10x-1 to 10x-25) were propagated in the greenhouse and in the field near Davis in 1988, along with the selfed offspring of decaploid 85.926-1.

'Seascape', a day-neutral octoploid $F . x$ ananassa cultivar, was pollinated with $F$. viridis and the 22 pentaploid offspring were studied (designated progeny 89.909). Three of them were self-fertile day neutrals. 'Capitola', also a day-neutral octoploid cultivar, was crossed with 'Alpine' $F$. vesca and one seed fertile day-neutral hybrid was obtained with complete pollen inviability.

Open-pollinated seeds from five decaploid seedlings of family 88.909 (designated selections 88.909-2, 88.909-35, 88.909-36, $88.909-42$, and 88.909-43) were germinated, and 25 seedlings of each were evaluated in the greenhouse for various fruit attributes. The remaining 480 open-pollinated seedlings were planted in the field in Davis in Apr. 1990 and one exceptional decaploid selection (89.906-6) was studied in the field during July and Aug. 1990 (Table 3).

Seed propagation and genetic and horticultural traits of decaploids. Seeds of the polyploids were germinated by scarifying them for $20 \mathrm{~min}$ in concentrated sulfuric acid, washing them with distilled water, and planting them in the greenhouse under incandescent light. Germinated seeds were transplanted once in the greenhouse, then transplanted to the field in late fall or early spring. The runners were counted twice a year in all populations. At least 25 plants from each population were randomly selected, and the size and viability of their pollen was estimated using acetocarmine stain. Plants were categorized for pollen viability: $<0.5 \%$, sterile; between $0.5 \%$ and $6 \%$, semi-sterile; between $6 \%$ to $20 \%$, semi-fertile (low to medium); $>20 \%$, fertile to highly fertile. The viability of their megaspores was estimated by obtaining the percentage of fertile seeds in each fruit, in the above plants, from each population.

Total yield, fruit size, soluble solids concentration (SSC; \%), 
Table 3. Ploidy and size, range in size and fertility of pollen, seed fertility, total yield; fruit weight; soluble solids concentration (SSC); and number of runners per strawberry plant of parents and their selected offspring.

\begin{tabular}{|c|c|c|c|c|c|c|c|c|c|c|}
\hline & \multirow[b]{3}{*}{ Ploidy } & \multicolumn{3}{|c|}{ Pollen } & \multirow{3}{*}{$\begin{array}{c}\text { Seed } \\
\text { fert }(\%)\end{array}$} & \multirow{3}{*}{$\begin{array}{l}\text { Total yld } \\
\text { (g/plant) }\end{array}$} & \multirow{2}{*}{\multicolumn{2}{|c|}{ Fruit size }} & \multirow{3}{*}{$\begin{array}{l}\text { SSC } \\
(\%)\end{array}$} & \multirow{3}{*}{$\begin{array}{c}\text { Runners/ } \\
\text { plant }\end{array}$} \\
\hline & & \multicolumn{2}{|c|}{ Size $(\mu)$} & \multirow{2}{*}{$\begin{array}{l}\text { Fert } \\
(\%)\end{array}$} & & & & & & \\
\hline & & Mean & Range & & & & g & SD & & \\
\hline$F$ vesca $^{z}$ & $2 x$ & 19 & $17-24$ & 99 & 99 & 18 & 0.7 & 0.2 & 9.6 & 33 \\
\hline$F$. vesca & $4 x$ & 25 & $22-26$ & 63 & 61 & 9 & 0.3 & 0.4 & 9.5 & 28 \\
\hline $87.803-1$ & $5 x$ & 30 & $25-34$ & 3 & 7 & 36 & 4.2 & 1.6 & 12.3 & 26 \\
\hline $87.802-1$ & $5 x$ & 30 & 24-34 & 2 & 8 & --- & --- & --- & -- & 32 \\
\hline $89.909-2$ & $5 x$ & 30 & $24-36$ & 2 & 38 & 68 & 5.1 & 0.6 & 9.2 & -- \\
\hline 'Chandler'y & $8 \mathrm{x}$ & 27 & $23-29$ & 87 & 83 & 578 & 13.5 & 4.8 & 8.4 & 48 \\
\hline 'Mrak'y & $8 x$ & 27 & $24-29$ & 85 & 86 & 788 & 9.2 & 2.8 & 8.4 & 33 \\
\hline 'Fern'y & $8 x$ & 27 & $23-30$ & 85 & 85 & 1539 & 9.5 & 3.0 & 7.6 & 29 \\
\hline $88.909-42$ & $10 \mathrm{x}$ & 30 & $26-33$ & 48 & 58 & 1578 & 8.1 & 2.8 & 8.2 & 31 \\
\hline $88.909-35$ & $10 \mathrm{x}$ & 31 & $26-35$ & 49 & 46 & 1174 & 5.2 & 1.9 & 10.8 & 21 \\
\hline $88.909-2$ & $10 \mathrm{x}$ & 30 & $27-33$ & 57 & 56 & 1120 & 4.1 & 1.1 & 11.8 & 0 \\
\hline $88.909-43$ & $10 \mathrm{x}$ & 31 & $26-35$ & 51 & 49 & 577 & 6.8 & 3.6 & 12.2 & 53 \\
\hline $88.909-15$ & $10 x$ & 30 & $26-34$ & 54 & 51 & 452 & 3.3 & 2.2 & 8.8 & 23 \\
\hline 88.909-36 & $10 x$ & 30 & $26-33$ & 75 & 80 & 381 & 4.1 & 1.3 & 7.6 & 28 \\
\hline $89.906-6^{x}$ & $10 x$ & 30 & $24-36$ & 60 & 59 & 681 & 12.8 & 3.6 & 10.2 & 16 \\
\hline $10 x-3$ & $10 \mathrm{x}$ & 31 & $25-36$ & 52 & 57 & 222 & 6.4 & 0.9 & 15.8 & 37 \\
\hline $86.832-23$ & $10 x$ & 30 & $25-33$ & 86 & 67 & 79 & 2.4 & 0.4 & 7.7 & 92 \\
\hline $86.832-22$ & $10 x$ & 30 & $25-34$ & 58 & 65 & 75 & 2.1 & 0.5 & 8.2 & 83 \\
\hline $86.831-27$ & $10 x$ & 30 & $25-34$ & 73 & 68 & 69 & 2.4 & 0.4 & 8.2 & 97 \\
\hline
\end{tabular}

'European $F$. vesca 'Alpine'.

${ }^{y} F$. xananasa.

xPlanted in Apr. 1990; examined July - Aug. 1990.

and aroma were measured or judged (by us) for each decaploid seedling and weekly yield and fruit weight were measured on 14 decaploid selections from family 88.909 from mid-April to early September, and the results were compared with those of the standard octoploid cultivars; day-neutral 'Fern' and shortday 'Chandler'. Soluble solids concentration was measured with a refractometer for 10 primary fruits of each clone in mid-Apr. 1990-91. Three clones of population 88.909 (88.909-35, 88.90942 , and 88.909-43) and clone 10x-3 were examined cytologically for chromosome number (after the method of Bringhurst and Gill, 1970). Thereafter, the ploidy levels of the other seedlings were judged by the morphology of their leaves and flower, the thickness of their runners, and the size and fertility of their pollen and seeds, compared with those of the octo- and the enneaploid plants.

Disease-resistance tests. 'Alpine' F. vesca, California $F$. vesca, and the hybrids of European and Californian diploids and pentaploids 87.803-1 and 87.802-1 were planted side-by-side in Watsonville, Calif., to evaluate their tolerance to Mild Yellow Edge virus infection. The above two pentaploids, 'Alpine' and clones of California $F$. vesca, and a few decaploid progeny of 87.803-1 were tested for reaction to anthracnose (Colletotrichum acutatum Simmonds) using the method of Winterbottom (1989), i.e., young runners were sprayed with inoculum and kept in a growth chamber at $31 \mathrm{C}$ with $100 \%$ humidity for 5 to 7 days, and then examined for lesions.

\section{Results and Discussion}

Decaploid strawberries derived from wild species of Fragaria (through 1987). All colchicine-derived interspecific decaploid hybrids (Ia, Ib) from wild species were fertile. Decaploids originating from $F$. virginiana sources such as 83.242-1, 88.909-36, and selected clones of 86.831 and 86.832 exhibited gametic viability in the range of $60 \%$ to $95 \%$ (Table 2). The pentaploid interspecific hybrids (Id, Ih) was ranked low to moderate (1\% to $8 \%$ ) for viable unreduced gametes (Table 2 and 3). Use of 16x, 12x and 9x interspecific hybrids to obtain decaploid plants was, at best, marginally successful based on the observed functional male gametes and production of fertile seeds. Consequently, their employment as parental materials for further study may not work at all. In particular, the dodecaploids derived from octoploid Fragaria spp. exhibited almost total sterility (functionally polytriploids) and $12 x$ and 9x strawberries derived from $F$. moschata were cross-incompatible with the octoploid species.

The performance traits of the offspring of the above natural decaploid derivatives are compared in Table 2. Most decaploid seedlings exhibited apparent heterosis for vegetative traits, such as number of runners, size and vigor of plants, and thickness of leaves and petioles. The selfed and open-pollinated offspring of the colchi-decaploid hybrids (progenies 87.813 and 87.814), however, exhibited inbreeding depression in vegetative vigor and fertility. Although mega- and microspore viability were fairly good in some selections, their total yield, fruit size, and fruit quality were much inferior to those of the octoploid cultivars of $F$. xananassa (Table 2). Decaploid strawberries derived from $F$. chiloensis had larger fruits and achenes than those of the other decaploid interspecific hybrid strawberries. Many seedlings derived from 'Alpine' $F$. vesca were aromatic with excellent flavor, as also reported by other investigators (Bauer and Grubler, 1962; Scott, 1951). The above decaploid populations ranged broadly in fruit firmness (measurements with Hunter Force Gauge equipped penetrometer) in contrast to only soft fruits reported by Scott (1951); our results suggested that firmfruited strawberries may be bred readily at the decaploid level. The results of the field and the greenhouse studies also revealed that decaploids resistant to many diseases, including mildew, anthracnose, and virus diseases such as Mild Yellow Edge, may be selected. 
Desirable fruit qualities, such as high yield and large size may be introduced easily into the decaploids from selected cultivars of $F$. ×ananassa, just as those traits were probably obtained from clones of $F$. chiloensis selected by Chilean aborigines long before the conqust (Table 2). It should be noted that the important octoploid ancestral species of Fragaria were found only on the American continents and, to a limited extent, on a few islands of the Pacific Ocean. In contrast, diploid species of Fragaria are more widespread than octoploid species, being native to Europe, Asia, and America. These natural diploid populations are characterized by high genetic diversity, and there is evidence for local and regional adaptation that may be very useful in future strawberry breeding programs throughout the world. Combining them with the octoploid genomes at the decaploid level appears to be potentially rapid and simple. In addition, the diploids with only one known exception (Calif. $F$. vesca ssp. bracteata Heller) are hermaphroditic, whereas the colchi-decaploids derived from female or male natural octoploids remain females or weak hermaphrodites, respectively, in the first generation of hybridization (Ahmadi and Bringhurst, 1991).

Day-neutral decaploids, their origin and their value (198790). The octoploid cultivars of California hybridized readily with selected wild clones of $F$. viridis from Eurasia, $F$. vesca from California, and $F$. iinumae from Japan, but some difficulties were encountered in hybridizing them with 'Alpine' $F$. vesca from Europe. The difficulty with 'Alpine' $F$. vesca apparently may be overcome with proper parental selection. For example, a vigorous selfed seedling of 'Mrak' was hybridized with 'Alpine' F. vesca and the pentaploid hybrid (87.803-1, Table 3) was day-neutral and semi-fertile. Its functional gametes were largely unreduced, and it yielded relatively large fruits (4 to $8 \mathrm{~g}$ ) in Watsonville in 1987. The presumed day-neutral enneaploid seedlings of 87.803-1 were invariably infertile when attempts were made to hybridize them to octoploid strawberry cultivars, whereas the open-pollinated day-neutral decaploid seedlings of the above pentaploid clone (87.803-1) and decaploid strawberries of 1986, ranged from highly fertile $(>50 \%)$ to sterile $(<0.5 \%)$. The day-neutral offspring of $87.802-1$ crossed with the colchi-decaploid 85.926-1 also ranged from highly fertile to sterile. The day-neutral clone $(87,802-1)$ also was hybridized with hexaploid $F$. moschata cultivar 'Capron', a hermaphroditic clone of hexaploid $F$. moschata, to yield dayneutral interspecific octoploid hybrids and possibly facilitate the transfer of desirable genes from the hexaploid to the octoploid level. The offspring had excellent pollen, but were seed sterile.

The initial results of breeding for fruit size, total yield, and viability of gametes were very encouraging (Table 3). Yield and fruit size of the best decaploid selections compared favorably with those of the standard octoploid cultivars, in addition to manifesting evidence of superior tolerance to the intense summer heat of the central valley of California (Tables 3 and 4).

The day-neutral decaploid selections were aromatic, good flavored, and their fruit texture ranged from soft to firm. Some demonstrated resistance to mildew, anthracnose, and virus infection in the greenhouse and in the field. The quality of their fruits could be improved by additional intercrossings and backcrossing and selection among parents derived from certain $F$. virginiana selections (e.g., 88.909-36, Table 3). The open-pollinated seedlings of selected 1989 clones were planted in Apr. 1990. Their yield and fruit quality were even more encouraging. Fruit size and yield data of one of the best selections are included in Table 3. The newly derived day-neutral pentaplid hybrids of 'Capitola' with $F$. vesca 'Seascape' with $F$. viridis had relatively high micro- and megaspore fertility, ranging to $38 \%$.

Previously, Scott (1951), Bauer and Grubler (1962), Spiegler et al. (1986), and MacIntyre and Gooding (1977) included a few short-day $F$. ×ananassa cultivars in their decaploid breeding programs. Although they reported improvement in yield, fruit size, quality, and runnering in their decaploid strawberries they encountered challenges. They used a few semi-sterile to semi-fertile hexaploid clones derived from colchicine derived tetraploids of 'Alpine' F. Vesca and exclusively short-day cultivars of $F$. Xananassa. The subsequent backcrossing of the synthesized hexaploids to $F$. xananassa produced few decaploid plants among a host of aneuploid offspring with chromosome numbers ranging from 47 to 77 (Scott, 1951). In addition, their decaploid plants reportedly did not perform well in regions other than those in which they were tested and all were shortday types.

In our study, pentaploid clones, homozygous for day-neutrality and that produced a high percentage of functional unreduced gametes, were obtained by crossing day-neutral $F$. xananassa cultivars and diploid $F$. vesca and $F$. viridis. These were then selfed and intercrossed with decaploid parental stocks of short-day origin to obtain improved day-neutral decaploid seedlings. The populations were day-neutral, without exception, since the day-neutrality trait involved is dominant (Ahmadi et al., 1990). Decaploid seedlings were selected and evaluated for desirable fruit and performance traits to breed vigorous hybrid offspring. This procedure evidently generates populations that exhibit desirable levels of variability without inbreeding depression in open-pollinated populations of their offspring, unlike the high levels of homozygosity and inbreeding depression that result when seedlings are obtained from essentially homozygous colchi-decaploid parents, such as those we used in 1986.

Breeding strategy and the transfer of desirable genetic traits. Many investigators have described the availability and importance of desirable traits in wild species of Fragaria by screening the natural clones (Bringhurst et al., 1966; Darrow, 1966; Gooding et al., 1981; Kurosawa and Hara, 1960; MacIntyre and Gooding, 1977; Scott, 1951; Spiegler et al., 1986). These reports noted the possibility of transferring genetic resistance (tolerance) to disease, pests, and environmental stress in addition to traits for improvement of fruit quality and total yield.

The first step in a viable decaploid breeding program is hybridization of octoploid with diploid clones derived or selected from natural populations of Fragaria spp. and doubling the chromosome complement of the pentaploid hybrids to derive adapted and stress- and disease-resistant interspecific hybrid decaploid clones with adequate fertility. The second step involves the generation of semi-sterile to semi-fertile day-neutral pentaor hexaploid clones from hybridizing day-neutral octoploid cultivars and natural diploid or tetraploid strawberry progenitors to transfer genes conditioning high yield, large fruit, acceptable firmness, good fruit quality, and reduced generation time to decaploid strawberry cultivars. At this point, the final ploidy level in achieving the above goal may be decaploid for many genes derived from diploid species, and octoploid for other desirable traits, particularly those from natural hexaploid populations of F. moschata, as Evans (1974) has noted.

A recurrent hybridization strategy (mostly backcrossing in the broad sense), involving the use of two parental materials, one sampling the gene pool of the natural species and the other bringing in the necessary traits from the octoploid cultivars, 
Table 4. Biweekly yield (above) and fruit size (below) of selected decaploid day-neutral strawberry seedlings compared with those of short-day ('Chandler') and day-neutral ('Fern') cultivars.

\begin{tabular}{|c|c|c|c|c|c|c|c|c|c|c|c|c|}
\hline \multirow[b]{2}{*}{ Item } & \multirow[b]{2}{*}{ Ploidy } & \multirow[b]{2}{*}{$\begin{array}{c}\text { Photo } \\
\text { type }\end{array}$} & \multicolumn{9}{|c|}{ Yield ( $\mathrm{g} /$ plant) for 2-week periods ending: } & \multirow[b]{2}{*}{$\begin{array}{c}\text { Total } \\
\text { (g/plant) }\end{array}$} \\
\hline & & & $\begin{array}{c}26 \\
\text { Apr. }\end{array}$ & $\begin{array}{c}12 \\
\text { May }\end{array}$ & $\begin{array}{l}31 \\
\text { May }\end{array}$ & $\begin{array}{c}14 \\
\text { June }\end{array}$ & $\begin{array}{c}29 \\
\text { June }\end{array}$ & $\begin{array}{c}12 \\
\text { July }\end{array}$ & $\begin{array}{c}8 \\
\text { Aug. }\end{array}$ & $\begin{array}{c}18 \\
\text { Aug. }\end{array}$ & $\begin{array}{c}6 \\
\text { Sept. }\end{array}$ & \\
\hline 'Chandler' & $8 \mathrm{x}$ & S-D & 307 & 176 & 74 & 21 & 0 & 0 & 0 & 0 & 0 & 578 \\
\hline 'Fern' & $8 \mathrm{x}$ & $\mathrm{D}-\mathrm{N}$ & 380 & 269 & 75 & 62 & 184 & 195 & 74 & 108 & 223 & 1569 \\
\hline $88.904-42$ & $10 \mathrm{x}$ & $\mathrm{D}-\mathrm{N}$ & 334 & 212 & 97 & 121 & 212 & 184 & 86 & 119 & 213 & 1578 \\
\hline $88.909-35$ & $10 \mathrm{x}$ & $\mathrm{D}-\mathrm{N}$ & 82 & 181 & 154 & 131 & 182 & 152 & 68 & 52 & 171 & 1174 \\
\hline $88.909-2$ & $10 \mathrm{x}$ & $\mathrm{D}-\mathrm{N}$ & 128 & 93 & 88 & 153 & 207 & 132 & 106 & 93 & 120 & 1120 \\
\hline $88.909-43$ & $10 \mathrm{x}$ & $\mathrm{D}-\mathrm{N}$ & 53 & 193 & 0 & 0 & 148 & 143 & 0 & 0 & 40 & 577 \\
\hline $86.831,832$ & $10 \mathrm{x}$ & $\mathrm{D}-\mathrm{N}$ & 86 & 27 & 32 & 26 & 0 & 22 & 12 & 18 & 22 & 246 \\
\hline \multirow[t]{2}{*}{$10 x-3$} & $10 \mathrm{x}$ & $\mathrm{D}-\mathrm{N}$ & 0 & 64 & 0 & 0 & 76 & 0 & 0 & 0 & 82 & 222 \\
\hline & & & \multicolumn{9}{|c|}{ Average fruit wt (g) } & $\begin{array}{c}\text { Season } \\
\text { mean }\end{array}$ \\
\hline 'Chandler' & $8 x$ & S-D & 16.1 & 12.3 & 6.4 & 5.8 & -- & -- & --- & -- & -- & 13.5 \\
\hline 'Fern' & $8 \mathrm{x}$ & $\mathrm{D}-\mathrm{N}$ & 14.3 & 11.7 & 9.7 & 7.5 & 7.6 & 6.9 & 6.9 & 5.9 & 6. & 9.7 \\
\hline $88.909-42$ & $10 \mathrm{x}$ & $\mathrm{D}-\mathrm{N}$ & 13.0 & 9.6 & 8.8 & 8.6 & 7.2 & 5.9 & 4.8 & 4.9 & 5. & 8.1 \\
\hline $88.909-35$ & $10 \mathrm{x}$ & $\mathrm{D}-\mathrm{N}$ & 8.6 & 7.7 & 5.3 & 5.5 & 3.8 & 4.5 & 2.2 & 3.4 & 4.0 & 5.2 \\
\hline $88.909-2$ & $10 \mathrm{x}$ & $\mathrm{D}-\mathrm{N}$ & 5.3 & 4.0 & 4.8 & 5.1 & 4.3 & 3.8 & 2.8 & 2.4 & 3.2 & 4.1 \\
\hline $88.909-43$ & $10 \mathrm{x}$ & $\mathrm{D}-\mathrm{N}$ & 14.2 & 6.5 & --- & --- & 5.6 & 4.4 & --- & --- & 3.4 & 6.8 \\
\hline $86.381,832$ & $10 \mathrm{x}$ & $\mathrm{D}-\mathrm{N}$ & 2.7 & 2.6 & 2.4 & 2.0 & --- & 2.0 & 1.8 & 1.8 & 1.5 & 2.3 \\
\hline $10 x-3$ & $10 x$ & $\mathrm{D}-\mathrm{N}$ & -- & 7.3 & -- & -- & 5.6 &.- & -- & $\ldots$ & 5.9 & 6.2 \\
\hline
\end{tabular}

should result in increased adaptation and enhanced fruiting in the resulting decaploid strawberries. However, the first-generation hybrids of octoploid cultivars and derived or selected clones of natural species of Fragaria at any ploidy level have been low yielding with poor fruit quality (e.g., 'Fern' $\times$ 'Luther' $F$. virginiana; Table 2). Backcrossing thereafter, with or without intercrossing these hybrids to the original cultivars, resulted in rapid improvements in levels of desirability. For example, a minimum of only three to four generations of backcrossing was necessary for transferring the day-neutral traits from $F$. virginiana glauca to octoploid cultivars (Ahmadi et al., 1990).

In this study, we attempted to derive decaploid clones with specific adaptation and resistance. Simultaneously, we tried to improve fruiting characteristics and yield of the decaploid selections derived from octoploid cultivars. For example, selections 87.802-1, 87.803-1, and some of their progenies exhibited evidence of resistance to mildew, anthracnose, Mild Yellow Edge virus and to summer heat stress. One of the diploid parents, ('Alpine' $F$. vesca) is highly resistant to mildew and anthracnose, but is so susceptible to Mild Yellow Edge that it is a useful virus indicator.

A pentaploid by decaploid and pentaploid by pentaploid scheme of breeding was adopted in this study to generate ample decaploid parental stocks with high yield and large fruit with acceptable quality. Then recurrent mass selection (the "pyramid" strategy), i.e., intercrossing the best decaploid genotypes, may be employed concentrating on those parents with the highest estimates of general combining ability in their progenies. In all cases, decaploids synthetically derived from carefully screened natural populations likely will provide genes that enhance the performance and adaptation of future decaploid strawberry cultivars.

\section{Literature Cited}

Ahmadi, H. and R.S. Bringhurst. 1991. Genetics of sex expression in Fragaria species. Amer. Journal of Botany 78:504-514.

Ahmadi, H. and R.S. Bringhurst, and V. Voth. 1990. Modes of in- heritance of photo-periodism in Fragaria. J. Amer. Soc. Hort. Sci. 115:146-152.

Bauer, R. and A. Bauer. 1979. Hybridzüchtung in der Gattung Fragaria: 'Spadeka' -eine neue Sorte mit dem Aroma der Walderbeere. Erwerbsobstbau 21:151-161.

Bauer, R. and F. Grubler. 1962. Fraguria L. Subgenera: Fragaria ananassa Duch. und F. vesca semperflorens Duch. Handbuch der Pflanzenzüchtung. Paul Parey, Berlin (VI), 514-546.

Bringhurst, R.S. 1990. Cytogenetics and evolution in American Fragaria. HortScience 25:879-881.

Bringhurst, R.S. and T. Gill. 1970. Origin of Fragaria polyploids. II. Unreduced and doubled unreduced gametes. Amer. J. Bot. 57:969976.

Bringhurst, R.S. and D.A. Khan. 1963. Natural pentaploid Fragaria chiloensis - F. vesca hybrids in coastal California and their significance in polyploid Fragaria evolution. Amer. J. Bot. 50:658661 .

Bringhurst, R.S. and Y.D.A. Senanayake. 1966. The evolutionary significance of natural Fragaria chiloensis X F. vesca hybrids resulting from unreduced gametes. Amer. J. Bot. 53:1000-1006.

Bringhurst, R.S., S. Wilhelm, and V. Voth. 1966. Verticillium wilt resistance in natural populations of $F$. chiloensis in California. Phytopathology 56:219-222.

Darrow, G.M. 1966. The strawberry. Holt, Rinehart and Winston, New York.

Evans, W.D. 1974. Evidence of a crossability barrier in diploid x hexaploid and diploid x octoploid crosses in the genus Fragaria. Euphytica 23:95-100.

Fedorova, N.J. 1934. Polyploid interspecific hybrids in the genus Fragaria. Genetica 16:524-541.

Gooding, H.J., R.J. McNicol, and D. MacIntyre. 1981. Methods of screening strawberries for resistance to Sphaerotheca macularis (Wall ex Frier) and phytophthora cactorum (Leb. and Cohn). J. Hort. Sci. 56:239-245.

Janick, J. and J.N. Moore. 1975. Advances in fruit breeding. Purdue University Press, West Lafayette, Indiana.

Jennings, D.L. 1988. Raspberries and blackberries: Their breeding, diseases and growth. Academia Press, London.

Kurosawa, S. and H. Hara. 1960. Cytotaxonomical investigations of Japanese plants. J. Jpn. Bot. 35:43-46. 
Lilianfeld, F.A. 1934. Karyologische und genetische Studien an Fragaria I. Ein Tetraploider fertiler Bastard zwischen F. nipponica $(\mathrm{n}=7)$ and $F$. elatior $(\mathrm{n}=21)$. Japan J. Bot. 6:425-458.

MacIntyre, D. and H.J. Gooding. 1977. Strawberry: Breeding at different ploidy levels. Scottish Hort. Res. Inst. 23:44.

Scott, D.H. 1951. Cytological studies on polyploids derived from tetraploid Fragaria vesca and cultivated strawberries. Genetics 36:311331.

Senanayake, Y.D.A. and R.S. Bringhurst. 1967. Origin of Fragaria polyploids. I. Cytological analysis. Amer. J. Bot. 54:221-228.

Spiegler, G., B. Schlindwein, and H. Schimmelpfeng. 1986. Unter- suchungen zur Selektion von dekaploiden Fragaria X vescana. Erwerbsobstbau 28:220-221.

Vorsa, N. and J.R. Ballington. 1991. Fertility of triploid highbush blueberry. J. Amer. Soc. Hort. Sci. 116:336-341.

Warrington, I.J. and G.C. Weston. 1990. Kiwifruit and management Ray Richards publisher with the New Zealand Society for Horticultural Science.

Winterbottom, C.Q. 1989. Resistance of strawberry to Colletotichum acutatum. Master Diss., Univ. of California, Davis.

Yarnell, S.H. 1931. Genetic and cytological studies in Fragaria. Genetics 16:422-454. 